\title{
The old and new significance of political economy in diplomacy
}

\author{
DONNA LEE AND DAVID HUDSON*
}

\begin{abstract}
In a growing number of countries diplomatic systems are being overhauled so that the commercial activities of diplomatic services have been centralised, the commercial activities of diplomats have been extended, and business interests have been formally integrated within diplomatic systems. These changes result directly from the tendency of governments to reorganise, and in many cases merge, their trade and foreign ministries, as well as the strategy of building formal business-government links within diplomatic institutions. While none of these features is unfamiliar to previous diplomatic systems, what is exceptional is the relative neglect of the commercial aspects of diplomacy within diplomatic studies. This lack of attention to the commercial and business elements of diplomacy in traditional theories of diplomacy means that we find ourselves trying to analyse contemporary changes to diplomatic organisation and practice without a suitable conceptual and analytical framework. Highlighting the significance of a political economy approach to diplomacy, and also engaging with orthodox approaches to diplomacy, this article begins to develop some analytical and conceptual tools to better identify, explain and understand changes in diplomatic systems as well as the increased influence of private interests in diplomatic practice now under way.
\end{abstract}

This article is informed by a concern with changes in diplomatic practice and organisation in a growing number of states: more specifically, the emerging importance attached to commercial elements of diplomacy. ${ }^{1}$ In North America, Europe, Southern Africa, and Asia, commercial diplomacy has become a foreign policy priority of various governments. To implement this new policy emphasis, governments have restructured their diplomatic institutions in a number of ways. Some states, for example Canada, Australia and Belgium, have reformed their organisational structures in quite dramatic fashion by merging their trade and foreign ministries into one department. ${ }^{2}$ Others, such as the United Kingdom (UK) and the Czech Republic, have created new joint bodies of these two ministries to coordinate commercial diplomacy. At the centre of these new diplomatic structures we find formal businessgovernment partnerships. Such partnerships are also present in states that have not introduced organisational reform, such as the United States (US), South Africa, Germany, Norway, Brazil, Sweden and Tunisia, and is evidence of the widespread

* The authors would like to thank Geoff Berridge, Brian Hocking, Dom Kelly, Kishan Rana, Wayne Shannon, and the anonymous referees for comments on an earlier draft of this article.

1 Commercial diplomacy is the work of public officials from Foreign Ministries and overseas missions and officials from other government departments such as Trade/Commerce as well as private economic actors in support of the business and finance sectors of the economy. Commercial diplomacy involves the promotion of inward and outward investment and the promotion of exports in trade.

2 Other countries with combined trade and foreign ministries include Albania, Austria, Fiji, Republic of Korea, Mauritius and New Zealand. 
prioritisation of commercial diplomacy in the international objectives of an increasing number of states. The development of formal business-government linkages within government as well as increased government spending in support of business interests are now a common feature of commercial diplomacy. In sum, governments are reorganising their diplomatic systems so that commercial activities are far more centralised and the commercial activities of diplomats are extended. More crucially, new diplomatic practices based upon the ascendancy of business interests within diplomatic systems have begun to emerge.

With such changes already established in many countries, and under consideration in many others, we may well be witnessing substantively significant changes to the practice of diplomacy in the twenty-first century: changes that are fashioned by commercial interests. What are the key features of this diplomacy? First, it combines the economic and the political at both domestic and international levels. Second, government-business partnerships have become the key organising principle as well as an attribute of the state in the world economy. Third, the public interest is conceptualised as a collective expression of private interests. As this article shows, some of these features are common to most diplomatic systems of the Western and non-Western world. What is uncommon, however, is the recognition of these features in the canon of diplomatic studies, ${ }^{3}$ rendering them present-but-invisible in most accounts of the theory of diplomacy and practice. Thus, while orthodox diplomatic studies might usefully explain traditional interstate high politics in bilateral and multilateral settings, it fails to identify, explain and understand many changes to diplomatic systems and in particular the increased influence of private interests in diplomacy which is of growing relevance today.

\footnotetext{
3 By canon of diplomatic studies we mean the body of work written by scholars largely from the UK and the US that forms the core reading material for diplomatic studies courses in UK and US universities. These include: G. Ball, Diplomacy for a Crowded World (London: Bodley Head, 1976): G.R. Berridge, Diplomacy: Theory and Practice, 2nd edn. (Basingstoke: Palgrave, 2002); François de Callières, The Art of Diplomacy, edited by M.A. Keens-Soper and K.W. Schweizer (Leicester: Leicester University Press, 1983); H. Kissinger, Diplomacy (New York: Simon \& Schuster, 1994); H. Nicolson, The Evolution of Diplomatic Method: Being the Chichele Lectures delivered at the University of Oxford in November 1953 (Leicester: Diplomatic Studies Programme, University of Leicester, 1998); Sir E. Satow, A Guide to Diplomatic Practice, 2nd edn. (London: Longman, 1922); Adam Watson, Diplomacy: The Dialogue between States (London: Eyre Methuen, 1982); A. de Wicquefort, The Embassador and His Functions (translated by J. Digby in 1716 and reproduced by the Centre for the Study of Diplomacy, University of Leicester, 1997). Also general texts such as R.P. Barston, Modern Diplomacy, 2nd edn. (London: Longman, 1997); G.A. Craig and A.L. George, Force and Statecraft: Diplomatic Problems of our Time (Oxford: Oxford University Press, 1995); A. Eban, Diplomacy for the Next Century (New Haven, CT: Yale University Press, 1998): C.W Freeman, Arts of Power: Statecraft and Diplomacy (Washington, DC: United States Institute of Peace Press, 1997); A. George, Forceful Persuasion: Coercive Diplomacy as an Alternative to War (Washington, DC: United States Institute of Peace Press, 1991); K. Hamilton and R. Langhorne, The Practice of Diplomacy (London: Routledge, 1995); P.G. Lauren, Diplomacy: New Approaches in History, Theory and Policy (New York: Free Press, 1979); ; W.B. Macomber, The Angel's Game: A Handbook of Modern Diplomacy (New York: Stein and Day, 1975); P. Marshall, Positive Diplomacy (Basingstoke: Macmillan, 1999); the chapter 'Diplomacy' in H. G. Morgenthau, Politics Among Nations: The Struggle for Power and Peace, 2nd edn. (New York: Knopf, 1955); E. Plischke, Modern Diplomacy: The Art and the Artisans (Washington, DC: American Enterprise Institute for Public Policy Research, 1979); M. Stearns, Talking to Strangers: Improving American Diplomacy at Home and Abroad (Princeton, NJ: Princeton University Press/Twentieth Century Fund, 1999); and A.L. Steigman, The Foreign Service of the United States: First Line of Defense (Boulder, CO: Westview Press, 1985). We also include the journal Diplomacy \& Statecraft within this canon. In using the term canon we do not wish to imply that diplomatic studies lacks diversity but argue that approaches that challenge this canon are rarely listed as core reading material.
} 
The current diplomatic system - a system in which commercial activities predominate in terms of the relative percentage of resources spent on them - challenges a number of inferences that are core to the dominant view of diplomacy found in the canon of diplomatic studies. These include structural inferences such as the separation of politics and economics in diplomatic processes and the conceptualisation of diplomacy as an autonomous political process as well as an attribute of the general political interest in the international political domain. Also included is the stronger inference that traditional diplomacy is the privileged domain of professional diplomats, conducted almost exclusively by Foreign Service personnel and officials from Foreign Ministries. We thus find ourselves conceptualising and analysing a diplomatic system that is at variance with the chief intellectual tenets of diplomatic studies. The challenge now is to develop a way of conceptualising and analysing diplomacy that can identify, explain and understand these sorts of changes to diplomatic practice.

This article takes up this challenge. It first asserts that diplomatic practice is and always has been much more than the traditional interstate high politics that it has largely been portrayed as, and in so doing rejects the implicit novelty of commercial diplomacy contained within traditional accounts. This is not to conclude that nothing has changed. Instead, the argument is that commercial diplomacy has always been an integral part of diplomatic practices, but that its form is currently undergoing restructuring, that is, the relationship between government and business is changing with important consequences for diplomatic practice.

In order to make such an argument the article will proceed as follows. First, it rehearses the traditional and popular account of diplomacy; that is, diplomatic relations are the very stuff of 'high' politics. Such an account is flawed because it is a partial, indeed singular, rendering of a more complex and multifaceted history of diplomatic practices. An explanation for this myopia is found in the way the academic relationship between diplomacy and International Relations (IR) is constructed. ${ }^{4}$ Thus the second part of the article concerns itself with how hegemonic interpretations of international relations serve to impose a contrived understanding of diplomacy. The article argues that the dominant interpretation revolves around a series of dichotomies that mask alternative 'origins' of diplomacy and diplomatic systems. Third, clearing the ground for a political economy approach, the article recounts some alternative origins of diplomatic practices, and thus their historical form. In order to explain the continued relative neglect of these alternative accounts the article engages with the theme of IR as an ongoing discourse. Once this is done, we will be in a better position to analyse the contemporary changes in diplomatic institutions first highlighted. The conclusion presents these as changes contained within an unbroken diplomatic tradition of ongoing public and private engagement, something that has been obscured by the predominant rationalist approach found in the diplomatic studies canon. In approaching diplomacy in the first instance as

\footnotetext{
4 We follow the conventional use of the nomenclature international relations and International Relations, respectively, to distinguish between 'belonging' and 'referring'. Lower-case international relations are those structures, agents and processes that belong to the realm that is the focus of study, and the capitalised International Relations, or IR, refers to conceptualisations of these and thus the discipline of study. The need to do this, as will become clear, is that although the two clearly relate to one another they do not necessarily correspond to each other.
} 
containing political and economic elements, analysis is then able to focus upon changing public-private relationships within state structures. We could then begin to address crucial issues which as yet have largely been ignored, remain paradoxical or unanswerable, in the current diplomatic studies schema and justify the need for a political economy approach to diplomacy. These would include for example:

- The changing institutional structures of national diplomatic systems;

- Normative issues regarding the relationship between private business interests and the public interest;

- The reconfiguring of diplomatic actor identities as private actors become officially involved in diplomatic processes;

- Discourses of a profession in peril.

The neglect of the economic dimension of diplomacy in orthodox studies has proved particularly costly in the study, for example, of the impact of non-state actors in multilateral and bilateral diplomacy. The scope for international business groups such as the International Chamber of Commerce, the World Economic Forum, and the Transatlantic Business Dialogue, to influence multilateral diplomacy at the international level has grown with the creation and development of, for example, the GATT/WTO, the United Nations and economic summits. ${ }^{5}$ And at the domestic level, there is a much broader scope of methods of bilateral diplomacy than is suggested by orthodox studies as a result of public-private networks found in the diplomatic services of many countries. ${ }^{6}$ Equally, orthodox studies tend to lose sight of the important expert and technical advice provided by epistemic communities who enjoy formal authority in multilateral and bilateral diplomacy especially since economic negotiations have become more technical and complex on issues such as intellectual property and services. ${ }^{7}$

\section{Constituting the canon}

... issues of trade; issues of investment, of science, of agriculture; issues of the environment, of transport, crime-fighting, drug-busting, all these things have now interrupted the traditional world of diplomacy.

... it is increasingly difficult to distinguish between what is political in diplomacy and what is economic, and indeed, whether there is a dividing line between the two which has any validity at all. ${ }^{8}$

5 See D. Kelly, 'The International Chamber of Commerce as a Diplomatic Actor', Discussion Papers in Diplomacy, no. 67 (The Hague: Netherlands Institute of International Relations 'Clingendael', 2000); G. Pigman, 'A Multifunctional Case Study for Teaching International Political Economy: The World Economic Forum as Shar-pei or Wolf in Sheep's Clothing?', International Studies Perspectives, 3 (2002), pp. 291-309; N. Bayne and S. Woolcock, The New Economic Diplomacy: Decision-making and Negotiation in International Economic Relations (Hampshire: Ashgate, 2003).

6 See series of articles by D. Lee, R. Coolsaet, E. Potter, and K. Rana in the 'Policy Forum on Commercial and Economic Diplomacy', in International Studies Perspectives, vol. 5 (2004), pp. 50-70.

7 See Bayne and Woolcock, The New Economic Diplomacy, pp. 61-2.

8 Excerpts from speech by Christopher Meyer, British Ambassador to the United States, 24 March 1998, Foreign and Commonwealth Office, 'The Future of Diplomacy', available at http://britaininfo.org/bistext/embassy/24mar98.stm. (accessed May 2000). 
Commercial Sections of Foreign Ministries and overseas missions, as well as Consuls, have always had an important role to play in commercial diplomacy. It is, however, Consular Sections of Embassies and Consuls that are most commonly associated with overseas commercial activity. The functional distinctions between the Consular Service and the Foreign Service have been reinforced historically by the development of entirely different career tracks for Commercial Officers, Consuls and the Foreign/Diplomatic Service in most if not all countries. The former were, and remain, the poorer cousins while the latter is the home of the high-flyers and also, perhaps more importantly, recruited from the social elite. Indeed, social and cultural factors have been significant factors in the perseverance of an irreverent attitude towards the commercial aspects of diplomacy. In the late nineteenth century and early twentieth century diplomats (who in Europe were predominantly from aristocratic family backgrounds) held the world of commerce (seen by diplomats as a middle-class world) in social contempt. These social and class divisions added to the prominent perception within Foreign/Diplomatic Services that Commercial departments were 'black holes', by high ranking diplomats who were horrified by the prospect of wining and dining middle-class businessmen and the downturn in their careers that commercial postings signified. ${ }^{9}$

Some of those who study diplomacy tend to view commercial diplomacy in a similar vein, seeing commercial work as peripheral rather than central to diplomatic practice. ${ }^{10}$ Yet if we adopt a deeper historical reading of international relations and make use of a broader range of diplomatic memoirs as well as government documentation, we can reveal a diplomacy that is multifaceted and much more inclusive than the orthodox literature on diplomacy suggests. These sources indicate that diplomatic activity covers many issues - not least economic and commercial issues - and that far from being a departure from traditional diplomacy, economic and commercial aspects are rudimentary to ancient, modern and contemporary diplomacy.

\section{The misrepresentation of commercial diplomacy}

In the partial and exclusive rendering of diplomacy that is most commonly given, the wider activities of diplomats - and especially their commercial work - are seen as departures from the more serious concerns of diplomats. The notion that the effectiveness and stature of 'traditional diplomacy' is being reduced as new issues encroach on to the diplomatic agenda is an all too familiar concern of the scholarly response to these changes. ${ }^{11}$ It was, for example, a key topic for discussion around a

9 D.C.M. Platt, Finance, Trade, and Politics in British Foreign Policy 1815-1914 (Oxford: Clarendon Press, 1969); E. Hambloch, British Consul: Memories of Thirty Years' Service in Europe and Brazil (London: George G. Harrap, 1938).

10 See, for instance, Barston, Modern Diplomacy; Berridge, Diplomatic Theory and Practice; Eban, Diplomacy for the Next Century; Hamilton and Langhorne, The Practice of Diplomacy; Plischke, Modern Diplomacy; Marshall, Positive Diplomacy; Steigman, The Foreign Service of the United States.

11 See, for example, G.S. Craig, 'The Professional Diplomat and his Problems, 1919-1939', World Politics, 4 (1952), pp. 144-58; M. Donelan, 'The Trade of Diplomacy', International Affairs, 45 (1969), pp. 605-16; S.M. Finger, Inside the World of Diplomacy: The US Foreign Service in a Changing World (Westport, CT: Praeger, 2002); G.F. Kennan, 'Diplomacy without Diplomats', Foreign Affairs, 76 (1997), pp. 198-212; Marshall, Positive Diplomacy. See P. Sharp, 'For Diplomacy: Representation and the Study of International Relations', International Studies Review, 1 (1999), pp. 33-57, for analysis of these arguments. In the US the debate usually focuses on the theme of the decline of the Department of State. See D. Acheson, 'The Eclipse of the State Department', Foreign Affairs, 49 (1971), pp. 593-606. 
short report titled 'Diplomacy: Profession in Peril?' at a recent Wilton Park conference held in London. ${ }^{12}$

Several personal accounts of diplomacy given by active or retired diplomats record what is mostly the high political content of diplomacy, presenting an incomplete record of their work. Nicholas Henderson's diaries of his service as British Ambassador in Warsaw, Paris, Bonn and Washington from 1969 to 1982 provide perhaps the best example of this. ${ }^{13}$ While Henderson claims to show that diplomacy is the management of a 'whole range of practical everyday matters between states', ${ }^{14}$ he provides few details of the daily work of the Embassies and their huge staffs. And while there is plenty of incidental mention of commercial work - visits to local industries, trade fairs and the like - there is no attempt to present this as a significant and integral part of diplomatic practice despite the importance to British trade interests of Paris, Bonn and Washington. How sharply this contrasts with, for example, the description of the work of the British Embassy in Iran covering some of the same period. Ambassador Anthony Parsons argues that his Embassy was dominated by commercial work:

By the end of 1975 I had, with the approval of the Foreign Office, reorganised the Embassy staff to meet our priorities. First came export promotion in all its aspects - dealing with the flood of business visitors and commercial enquiries, helping to organise trade promotions and trade delegations, seeking new commercial opportunities and feeding them back into the export promotion machine back home. ${ }^{15}$

Similarly, retired Indian Ambassador Kishan Rana states that during his career ' $\mathrm{I}$ found that over fifty percent of my time was devoted to economic work' ${ }^{16}$

It is certainly difficult to make much sense of these differing accounts of what comprises everyday diplomacy in the modern era. Like Henderson, most diplomats focus almost exclusively on the political content of diplomacy when describing the work of the diplomat. ${ }^{17}$ Also held over from the early twentieth century is the habit of discussing commercial work in pejorative terms. Henderson, for example, refers to commercial activities as 'humdrum'. Again, contrast this with Rana's statement that commercial activities are 'one of the most exciting arenas of modern diplomacy'. ${ }^{18}$ Of course, what we are identifying might be contrasting individual

12 C. Jennings and N. Hopkinson (eds.), Current Issues in International Diplomacy and Foreign Policy, vol. 1 (London: HMSO/Wilton Park, 1999).

13 N. Henderson, Mandarin: Diaries of an Ambassador 1969-1982 (London: Weidenfeld and Nicolson, 1995). Of course, there are probably market reasons for omitting details of commercial work. Would such a book sell as well?

14 Henderson, Mandarin, p. 2.

15 A. Parsons, The Pride and the Fall: Iran 1974-1979 (London: Cape, 1984), p. 37. Parsons subsequently regretted spending so much time on trade matters at the expense of political issues.

16 K. Rana, Inside Diplomacy (New Delhi: Manas Publications, 2000), p. 117.

17 See, for example, H. Brind, Lying Abroad: Diplomatic Memoirs (London: The Radcliffe Press, 1999); Lord Gladwyn, The Memoirs of Lord Gladwyn (London: Weidenfeld and Nicolson, 1972);

Henderson, Mandarin; M.F. Herz, Making the World a Less Dangerous Place - Lessons Learned from a Career in Diplomacy (Lanham: University Press of America, 1987); H. Kissinger, The White House Years (London: Weidenfeld and Nicolson, 1979); R.H. Miller, Inside the Embassy: The Political Role of Diplomats Abroad (Washington, DC: Congressional Quarterly Inc., 1992); J. Reeve, Cocktails, Crises and Cockroaches: A Diplomatic Trail (London: Radcliffe Press, 1999); Baron W. Strang, The Diplomatic Career (London: A. Deutsch, 1962).

18 Rana, Inside Diplomacy, p. 126. 
circumstance and interests. Yet the evidence of both Rana and Parsons suggests that Henderson, and others, might well be doing diplomats a disservice by presenting only a partial account of the everyday work of the Embassy and binding diplomatic identity to a narrow political schema.

That commercial diplomacy may be uninteresting is not the key issue for us. What is at issue is the inaccuracy that attends the representation of commercial work in the diplomatic studies literature. It simply does not make analytical sense to discuss diplomatic practice without recognising that commercial diplomacy makes up a significant part of diplomatic work. Nor does it make analytical sense to relegate commercial work as a diversion from, or a degeneration of, traditional diplomatic activities and concerns.

Modern diplomacy cannot be understood as separate functions but instead needs to be analysed as multifaceted work in which specialist tasks such as commercial work and information work are interrelated; so much so that it is often impossible to distinguish between the many activities of a diplomat. ${ }^{19} \mathrm{UK}$ government records support this view. Members of the UK Diplomatic Service complained, for example, that the Duncan Report on Overseas Representation ${ }^{20}$ had mistakenly divided commercial work into political and economic components rather than seeing commercial diplomacy as a composite activity involving both. This, some diplomats claim, led the Duncan Committee to exaggerate the benefits of encouraging private sector involvement in trade promotion (by recommending an increased role for UK Chambers of Commerce). They concluded that the Duncan Committee undervalued the role of professional diplomats in trade promotion. ${ }^{21}$ Even diplomats, therefore, are critical of the tendency of outside observers to limit diplomatic identity and processes to the political aspects of their work.

In a practical sense, in most posts, diplomatic missions are simply not involved in the affairs of high politics. At places other than, say, neighbouring capitals, and to some extent the capitals of the major or regional powers, the political relationship is a given and does not call for more than exchanges of views on significant global/ regional issues and bilateral developments. Perhaps the most useful account of the multifaceted nature of diplomacy is provided by Lord Trevelyan who describes the diplomat as 'an economist, a commercial traveller, an advertising agent' who '. . . continues to have a basic political job. ${ }^{22}$ The composite nature of diplomacy and the integration of political and economic interests in diplomatic practice is nowhere more striking than in the Levant area from the late sixteenth to the early nineteenth centuries. In 1582, direct agents of the Levant Company became British diplomats and, until 1805 (when the British government took over), the company paid the entire costs of providing a diplomatic service in the area. ${ }^{23}$ According to historical accounts, these diplomats combined the roles of royal representatives and com-

\footnotetext{
19 J. Dickie, Inside the Foreign Office (London: Chapmans, 1992); C. Mott-Radcliffe, Foreign Body in the Eye: Memoir of the Foreign Service Old and New (London: Leo Cooper, 1995); Rana, Inside Diplomacy.

20 Review Committee on Overseas Representation Report of the Review Committee on Overseas Representation, Cmnd 4017, The Duncan Report. (London: HMSO, 1969).

21 Foreign and Commonwealth Office, 1970 70/45 Parts A-D, London Public Records Office, Kew.

22 Dickie, Inside the Foreign Office, p. 12.

23 A. Woods, A History of the Levant Company (Oxford: Oxford University Press, 1935).
} 
mercial agents with aplomb. ${ }^{24}$ Indeed, they were generally considered more effective in representing both national and trading influences than the regular officials of the General Consular Service. ${ }^{25}$ Similarly, the English East India Company and the Dutch East India Company forced the flag to follow trade throughout the East from 1600 to the early nineteenth century. ${ }^{26}$ In the UK 'the search for new markets and new distributive systems had been a national priority' 27 and meant that the company's ship commanders, such as William Hawkings, were 'entrusted with all diplomatic negotiations'. ${ }^{28}$ These composite characteristics are also evident elsewhere and especially in formative US diplomacy. ${ }^{29}$ In the eighteenth century, debates on isolationism between Hamilton, Jefferson and Madison focused on questions of appropriate balance between minimal political connection and maximum commercial relations. ${ }^{30}$ Much later, the historian Williams described the newly independent US as a 'mercantilist state' and highlighted the policy of 'open-door imperialism' to describe shifts in emphasis in US diplomacy from territorial expansion to the promotion of free trade to secure open markets. ${ }^{31}$

In sum, a closer reading of diplomatic memoirs as well as official documentation, and a deeper dip into diplomatic history, reveals a diplomacy that is multidimensional. These sources indicate that diplomatic activity is primarily concerned with the building of economic and commercial relations and that it is sometimes concerned with political relations. Thus, far from being a departure from traditional diplomacy, the economic and commercial aspects are fundamental to it.

\section{Commercial diplomacy: present-but-invisible}

Key to our discussion about commercial diplomacy is why it should attract so little attention; certainly, at least, for the scholars of diplomacy, and those who study

24 D.C.M. Platt, The Cinderella Service: British Consuls Since 1825 (London: Longman, 1971); Woods, A History of the Levant Company.

25 Platt, The Cinderella Service. For a critical view of Levant diplomats see D.B. Horn, The British Diplomatic Service 1689-1789 (Oxford: Clarendon Press, 1961).

26 For details see K.N. Chaudhuri, The English East India Company: The Study of an Early Joint-Stock Company 1600-1640 (London: Frank Cass, 1965); K.N. Chaudhuri, The Trading World of Asia and the East India Company 1660-1760 (Cambridge: Cambridge University Press, 1978); A.K. Smith, Creating a World Economy: Merchant Capital, Colonialism and World Trade, 1400-1825 (Boulder, CO: Westview Press, 1991); J.D. Tracy (ed.), The Rise of Merchant Empires: Long-Distance Trade in the Early Modern World, 1350-1750 ( Cambridge: Cambridge University Press, 1990).

27 J. Keay, The Honourable Company: A History of the English East India Company (London: HarperCollins, 1993), p. 52.

28 Keay, The Honourable Company, p. 74. For detail on the Dutch East India Company, see J. Van Goor 'India and the Indonesian Archipelago from the Generale Missiven der VOC (Dutch East India Company)', Interario, XVI (1992), pp. 23-37.

29 D.M. Pletcher, The Diplomacy of Involvement: American Economic Expansion Across the Pacific, 1784-1900 (Columbia, MO: University of Missouri Press, 2001).

30 See, for example, S. Doran, The Origins of Jeffersonian Commercial Policy and Diplomacy (Studies in Modern History, New York: Macmillan/St. Martin's Press, 1993); and R. Horsman, The Diplomacy of the New Republic, 1776-1815 (The American History Series, Arlington Heights, IL: Harlan Davidson, 1985).

31 W.A. Williams, A William Appleman Williams Reader: Selections from His Major Historical Writings (edited with an introduction and notes by H.W. Berger (Chicago, IL: I.R. Dee, 1992): and The Tragedy of American Diplomacy, 2nd revised and enlarged edition (New York: Dell, 1972). 
international relations. At one level, given many of the similarities between the subject-matter of international relations and diplomacy, this mutual inattention appears unremarkable. However, at a deeper level of analysis there is a more informative relationship to be teased out between IR and diplomatic studies. For us, this scholarly marginalisation of commercial diplomacy arises from deeper and more structural reasons than an arbitrary decision about what or what not to study. We argue that the sources of this neglect are found in the way in which both diplomatic studies, and IR more generally, conceive of their fields of study. It is within the dominant discourses about what, who, and how to study, that this paradox of commercial diplomacy's simultaneous presence-but-invisibility is explicable. ${ }^{32}$ In moving towards explaining this paradox, this section of the article develops an account of how its dynamics are reproduced by its adherence to the dominant IR approach - rationalism. ${ }^{33}$

There have been two themes running through and informing our arguments so far. First, an historically open-ended interpretation of the nature of international relations, and second, the interdependence of the various spheres of social life. Together, the two themes comprise our basic ontological position, and are essentially empirical claims that are elaborated upon in the rest of the article. The first theme then, is that the nature of the actors and the manner in which they are structured vary through history. The second theme is the significance of cultural and economic, rather than just political intercourse in providing a complete account of 'relations' that occur within this environment. ${ }^{34}$ In other words, these other sources of social power are also significant to the study of world affairs, rather than just (one particularly narrow definition of) political power. Moreover, in keeping with the first theme, the manner in which these different elements interact varies through time. These two themes - the historically constituted nature of international relations, and the pervasive significance of socioeconomic factors - tend to be absent in rationalist approaches to IR which, as we will show, inform orthodox diplomatic studies.

Focusing upon these two themes allows us to highlight a series of dichotomies that sustain the particular picture of diplomacy and international relations. Namely, one of political relations between states where 'diplomatic theory is the constitutional theory of a state-system' 35 and diplomatic practice is mostly a process of high political negotiation. This renders much of what goes under the mantle of world affairs invisible and fails to provide a full account of diplomatic practices that includes, for example, the building of bilateral economic relations through the promotion of inward and outward investment as well as export promotion. We identify three dichotomies in particular, which operate to reproduce the orthodox rendering of IR and diplomacy: these are the international/domestic, political/economic, and

32 The thrust of our argument owes much to the insights of R. Tooze and C.N. Murphy, 'The Epistemology of Poverty and the Poverty of Epistemology', Millennium: Journal of International Studies, 25 (1996), pp. 681-707.

33 Following Steve Smith, 'The United States and the Discipline of International Relations: Hegemonic Country, Hegemonic Discipline', International Studies Review, 4 (2002), pp 67-85, we use rationalism to refer to realism, neorealism and neoliberalism.

34 By 'just political intercourse' we are actually referring to a particularly narrow type of politics; perhaps that most closely associated with political-military relations.

35 M. Keens-Soper, 'Callières' in G.R. Berridge, M. Keens-Soper and T. Otte, Diplomatic Theory from Machiavelli to Kissinger (Basingstoke: Palgrave, 2001), p. 101. 
public/private, and in each conceptual opposition it is the former term that is privileged. Hence IR and diplomacy are the study of the international realm of states (public, political power). As such, the three dichotomies 'work' in a mutually supportive manner. For IR and diplomacy the study of the domestic, economic and private is simply not the stuff to help resolve the problems of anarchy. However, a key point amongst critics of this particular constitution of IR and diplomacy is that these conceptual oppositions are unsustainable. ${ }^{36}$ They are artificial constructions of an otherwise contingent whole. They render a partial account of origins and required practices while silencing alternatives.

One of the ways to understand the present-but-invisible status of commercial diplomacy within most diplomatic studies is to examine its intellectual history, and in particular the imprint of rationalist thinking on theories of diplomacy. ${ }^{37}$ This imprint is most evident in the statist approach underpinning the conceptualisation of diplomacy in this literature. The statist approach sees diplomacy as the study of the international realm of sovereign states and public political power, with the purpose of diplomacy being to overcome anarchy and facilitate peaceful relations. Or, as Watson expresses it, 'to reconcile the assertion of political will by independent entities' ${ }^{38}$ Indeed, it is the very fact of anarchy that, according to most theories of diplomacy, warrants the emergence of a diplomatic system. ${ }^{39}$

\section{The modern idea of diplomacy}

Making distinctions between politics and economics, between private and public, and between international and domestic, diplomacy is generally conceived of in two

36 For instance, see R. Ashley, 'Untying the Sovereign State: A Double Reading of the Anarchy Problematique', Millennium: Journal of International Studies, 17 (1998), pp. 227-62; R. Ashley 'The Powers of Anarchy: Theory, Sovereignty, and the Domestication of Global Life', in J. Der Derian (ed.), International Theory: Critical Investigations (London: Macmillan, 1995); D. Campbell, Writing Security: United States Foreign Policy and the Politics of Identity (Manchester: Manchester University Press, 1998); R.J.B. Walker, Inside/Outside: International Relations as Political Theory (Cambridge: Cambridge University Press, 1993).

37 For evidence of the rationalist ontological heritage in the theory of diplomacy we can point to Berridge et al., Diplomatic Theory. This useful guide to the diplomatic classics clearly defines the canon of the theory of diplomacy. Similarly, see P.G. Lauren, Diplomacy: New Approaches in History, Theory and Policy (New York: Free Press, 1979).

38 A. Watson, Diplomacy, p. 15.

39 See, for example, H. Butterfield and M. Wight (eds.), Diplomatic Investigations (London: George Allen \& Unwin, 1966); H. Bull, The Anarchical Society (Basingstoke: Macmillan, 1977); Donelan, 'The Trade of Diplomacy'; and Watson, Diplomacy. Even where the subject matter of diplomacy is economic rather than political relations or foreign policy, for example in case studies of oil diplomacy, financial diplomacy, and trade diplomacy, it is common for scholars to discuss the political power of states in their economic relations or to study the structural power of states in the international political economy. See, for example, Feis, The Diplomacy of the Dollar:1919-1932 (New York: Norton, 1996); R.N. Gardner, Sterling-Dollar Diplomacy in Current Perspective: the Origins and Prospects of Our International Economic Order (New York: Columbia University Press, 1980); D.B. Kunz, Economic Diplomacy of the Suez Crisis (Chapel Hill: North Carolina Press, 1991); R.H. Meyer, Bankers Diplomacy: Monetary Stabilization in the Twenties (New York: Columbia University Press, 1970); F. Venn, Oil Diplomacy in the 20th Century (Basingstoke: Macmillan, 1986); and R. Zimmerman, Dollars, Diplomacy and Dependence: Dilemmas of US Economic Aid (Boulder, CO: Lynne Rienner, 1993). Diplomacy is seen as (a) a state-centric system to overcome conflict/anarchy, and (b) primarily a tool of public political power to achieve common economic goals. 
ways. Broadly defined, diplomacy is a process of communication, negotiation and information-sharing between sovereign states. More narrowly defined, diplomacy is also a foreign policy instrument that belongs (almost exclusively) to states in an international system of anarchy. As a process of communication, negotiation and information-sharing, diplomacy largely revolves around the activities of professional (public) political actors and representatives of the state working in foreign ministries, permanent residencies or in international organisations.

However diplomacy is defined, the consensus view is that it has a constitutive function; it is a means of ordering the relations between states. In its most elevated status, diplomacy is 'essential to the difference between peace and war' and the 'bulwark against international chaos' ${ }^{40}$ as well as an ordering principle that can create balances of power. ${ }^{41}$

Thus conceptualised, the study of diplomacy, as both process and policy instrument, is primarily focused on states and is concerned with the conduct and content of interstate relations and foreign policy. It would be wrong to say, however, that this is the exclusive focus of diplomatic studies. Recently, there has been discussion and recognition of the widening content of diplomacy and also of the emergence of non-state actors as diplomatic agents as well as diplomatic actors found in other government departments. But the literature on these new areas of diplomacy environmental diplomacy, public diplomacy and commercial diplomacy ${ }^{42}-$ has not found its way into the mainstream of diplomatic studies which still largely concerns itself with what Marshall calls the political foreground. ${ }^{43}$

This is not to argue, however, that diplomatic studies lacks a dynamic approach to diplomacy. Existing accounts of diplomacy have readily and accurately identified diplomacy as a changing process in which diplomatic practice and methods are subject to adjustment in response to both systemic and domestic factors. ${ }^{44}$ These include the overall increase in diplomatic activity and the new practices and processes - such as summit diplomacy and multilateral diplomacy - which have emerged in response to factors like the increase in the number of states in the international system and the development of international and regional organis-

40 Berridge et al., Diplomatic Theory, p. 1.

41 See, for instance, Kissinger, Diplomacy; Watson, Diplomacy.

42 An indicative bibliography includes: R.J. Albright, R.S. Johnson, D.J. Rothkopf and C.B. Johnstone, US Commercial Diplomacy, Study Group Papers (New York: Council on Foreign Relations, 1998); P.S. Chasek, Earth Negotiations: Analyzing Thirty Years of Environmental Diplomacy (New York: United Nations University Press, 2001); R.G. Darst, Smokestack Diplomacy: Cooperation and Conflict in East-West Environmental Politics (Cambridge, MA: MIT Press, 2001); R.S. Fortner, Public Diplomacy and International Politics: The Symbolic Constructs of Summits and International Radio News (New York: Praeger, 1994); J. Garten, R. Zoellick and J. Shinn, Riding the Tigers: American Commercial Diplomacy in Asia, Study Group Papers (New York: Council on Foreign Relations, 1998); A.C. Hansen, USIA: Public Diplomacy in the Computer Age, 2nd edn. (New York: Praeger, 1989): D. Hoffman, 'Beyond Public Diplomacy', Foreign Affairs, 81 (2002), pp. 83-95; D. Lee, Middle Powers and Commercial Diplomacy: British Influence at the Kennedy Trade Round (Basingstoke: Macmillan, 1999); J.B. Manheim, Strategic Public Diplomacy and American Foreign Policy: The Evolution of Influence (Oxford: Oxford University Press, 1997); P. Sharp, 'Making Sense of Citizen Diplomats: The People of Duluth, Minnesota, as International Actors', International Studies Perspectives, 2 (2001), pp. 131-50; H.N. Tuch, and M. Kalb Communicating with the World: US Public Diplomacy Overseas, Martin F. Herz Series on US Diplomacy (New York: Macmillan/St Martin's Press, 1990).

43 Marshall, Positive Diplomacy.

44 See Jennings and Hopkinson, Current Issues; P. Marshall and N. Ayad (eds.), The Dynamics of Diplomacy (London: Diplomatic Academy of London, 1990); Barston, Modern Diplomacy. 
ations. Further examples of dynamism are the numerous efforts to increase the professionalism and efficiency of diplomatic processes, which have led to the increased application of new technologies in diplomacy such as the recent innovative use of web pages in consulates and overseas embassies. We could also point to factors such as the greater level of public scrutiny of diplomacy and the increased involvement of government actors from outside Foreign Ministries and Foreign/ Diplomatic Services. As a result of these technological and organisational dynamics, modern diplomatic practice routinely involves rapid communications, less secrecy and increased informal public involvement, increased involvement of officials from other government departments as well as private actors. But while there has been widespread recognition and detailed discussion of procedural and substantive changes to diplomacy, this has not developed into a series of new discourses within contemporary diplomatic studies. The conceptual framework of diplomacy, the definition of diplomacy and the systemic environment of diplomacy has been constant in diplomatic studies from Wicquefort (1606-1682) to date. In essence the very idea of diplomacy - that it is a dialogue between states in an anarchic systemic structure of independent political units - has not changed all that much during some three hundred and fifty years of scholarship. The concern of this article is with the analytical obstacles this perpetuity poses for understanding and explaining significant but neglected areas of study that emerge when the political meets the economic - such as the interaction and contest between public and private interests within national and diplomatic systems.

How might this idea of diplomacy be explained? Where does this idea itself originate ${ }^{45}$ The predominant idea of diplomacy emerges in the various historical accounts of the development of diplomacy that assign prime significance to the diplomatic system of the Italian city-state system in the evolution of what is called 'modern diplomacy' that now operates around the world. With very few exceptions, ${ }^{46}$ most descriptions see the simultaneous emergence of the Italian city-state system and the first organised diplomatic system in the mid-fifteenth century. ${ }^{47}$ This historical reading establishes the idea that diplomacy is constituted by, and also constitutes, state sovereignty. State sovereignty, in turn, constitutes the anarchic systemic structures characterised by the separation of the domestic from the international, the economic from the political, and the private from the public.

The Italian city-state system of 'feverish competition between the small Italian states $^{48}$ emerges as the system that leaves a permanent imprint on the evolution of

45 A third question, why it became so predominant and immune to criticism in the field of diplomatic studies, is also relevant but space limitations prevent a full discussion here. A serious attempt to address this question can be found in J. Der Derian, On Diplomacy: A Genealogy of Western Estrangement (Oxford: Basil Blackwell, 1987).

46 Three notable exceptions are Der Derian, On Diplomacy; C.M. Constantinou, On the Way to Diplomacy (Minneapolis, MN: University of Minnesota Press, 1997), and J. Hoffman, 'Reconstructing Diplomacy', British Journal of Politics and International Relations, 5 (2003), pp. 525-42.

47 See M.S. Anderson, The Rise of Modern Diplomacy 1450-1919 (London \& New York: Longman, 1993); Berridge et al., Diplomatic Theory; Hamilton and Langhorne, The Practice of Diplomacy; R Langhorne, 'The Regulation of Diplomatic Practice: The Beginnings to the Vienna Convention on Diplomatic Relations, 1961', Review of International Studies, 18 (1992), pp. 3-17; Lauren, Diplomacy; G. Mattingly, Renaissance Diplomacy (Harmondsworth: Penguin/Jonathan Cape, 1955); Marshall, Positive Diplomacy; Nicolson, The Evolution of Diplomatic Method.

48 Nicolson, The Evolution of Diplomatic Method, p. 30. 
modern diplomatic practice. In his classic work, Harold Nicolson describes how the fall of the Roman Empire created a vacuum of political authority in which 'physically weak' states looked to 'diplomatic combinations' for their defence. Here is the classical realist explanation for the emergence of organised diplomacy and a balance of power. ${ }^{49}$ For example he argues that in the Italian system 'Policy ceased to be stated in the sharp alternatives of obedience or revolt, but became a question of adjusting rival ambitions' and 'it was then that professional diplomacy became one of the branches of statesmanship' and then spread across Europe. ${ }^{50}$ Others take Nicolson's description as a given, and proceed to argue that the Italian system became the first organised diplomatic network in the history of the international system 'formed on the basis of a system of interstate relations recognisable as the direct ancestor of the one which exists today. ${ }^{51}$

We can also note the rationalist ontological source of diplomatic studies in its explanation for the transhistorical nature of this system since the mid-fifteenth century. The system of diplomacy that emerged in this era is seen not only as the first diplomatic system in history, but it is one that would have a permanent imprint on diplomatic practice in the twenty-first century. This historical moment in the midfifteenth century, a moment that brings forth the unison of state sovereignty and an organised network of diplomacy, itself gives rise to an important conceptual schema - the prominent line that Europe is central to all international relations. From this point the power politics of Europe becomes the core empirical and conceptual focus of diplomatic studies (and IR) until at least the beginning of the twentieth century, if not beyond. This euro-centrism is evident in the mentors of the theory of diplomacy - Calliéres, Kissinger, Nicolson, Richelieu, and Wicquefort.

In this respect the historiography of the theory of diplomacy is not so much a case of the past informing the present, but is rather a means of allowing the present discourse to caricature the past. But this is not our chief concern. Our chief concern is more practical. The significance of the reading of the evolution of diplomacy presented in mainstream diplomatic studies is that it enables a specific political idea of diplomacy to take hold, one that focuses almost exclusively on political dialogues between states.

In the following two sections we will draw upon our ontological themes to locate alternative historical accounts of diplomatic practices and then begin to develop a political economy of diplomacy. First then, what of the claims that the international system is one shaped as much by socioeconomic as political-military relations?

\section{Diplomacy beyond the canon}

The arguments of Nicolson and others suffer a serious weakness in that there are recognised empirical anomalies in their historical account of the evolution of modern diplomacy. Two recent studies have argued that the historical account found in this prominent line of argument is misleading. Focusing on the significance of social power

\footnotetext{
49 See also Kissinger, Diplomacy.

50 Nicolson, The Evolution of Diplomatic Method, p. 24.

51 Anderson, The Rise of Modern Diplomacy, pp. 2-3,
} 
in international systems, Adda Bozeman's study of pre-modern international relations challenges the narrow political interpretation of diplomatic history presented by Nicolson and his followers. By discussing the interplay of politics and culture in world affairs, together with an extensive analysis of the 'non-western orbit' of the world system, including China and Islam, Bozeman identifies a much more complex and dense network of diplomatic systems than that presented by Nicolson. ${ }^{52}$ And by focusing on culture and social power she offers an analysis of the evolution of diplomacy in the context of world history in which non-Western cultures are not 'others' but are in fact integral to world society. In this schema, diplomacy is not reduced to the political dialogue between European states but is instead a series of social and political links and communications between different cultures; between, for example, Spain and Islam in the late fifteenth century or between the Ottoman Empire and the Venetian relazioni. Bozeman defines diplomacy as a series of connections on a grand scale between cultures, between peoples and between continents as well as states. States are not the only entities, cultures are also significant in world affairs so that international relations are defined as intercultural relations throughout the book. One of Bozeman's key points is that diplomacy is as much about cultural relations as it is about political relations and that culture, more so than politics, provides structuring principles in the evolution of diplomatic systems in this period and beyond. Bozeman presents a wealth of evidence of pre-Western incarnations of diplomatic systems that are not separate and autonomous but are connected in worldwide networks by culture and politics. Furthermore, she finds it difficult to accept Nicolson's particular description of the origins of the Italian diplomatic system. Nicolson 'clouds, 'misleads' and 'distorts' the history of diplomacy through his 'implicit assumption that there was an organised and effective system of diplomacy in medieval Europe' when, according to Bozeman, 'there was no organised system of diplomacy . . . before the Venetian was transplanted to the Italian and European courts. ${ }^{53}$ European diplomacy emerged as a result of the implant of Venetian methods, not out of the emergence of a new form of state - the sovereign state. By pointing to the Venetian heritage of European diplomacy - in which the Venetian organisation of diplomacy was not only transplanted but also adjusted to the specifics of Italian culture - Bozeman again identifies culture rather than state sovereignty as the structuring principle in the evolution of the European diplomatic system in this period.

Similarly, though from a different perspective, Rosenberg argues that the image of a modern state-system beginning in Italy misleads. ${ }^{54} \mathrm{He}$ challenges the supposed Italian origins of modern diplomatic systems so central to the modern conceptualisation of diplomacy. Rosenberg argues that the Italian city-states in this period were not an isolated, closed area developing their own system of diplomacy but were 'at the hub of the wheel' of a large commercial system in which they were able to

52 A. Bozeman, Politics and Culture in International History: From the Ancient Near East to the Opening of the Modern Age, 2nd edn. (Princeton, NJ: Princeton University Press, 1994). For a related study of ancient diplomacy that focuses on kinship, see C.P. Jones, Kinship Diplomacy in the Ancient World (Harvard: Harvard University Press, 1999). Scholars of international economic history also reveal a role played by culture in the development of international relations. See P.D. Curtin, Cross-cultural Trade in World History (Cambridge: Cambridge University Press, 1984); K. Pomeranz and S. Topik, The World That Trade Made (London: M.S.Sharp, 1999).

53 Bozeman, Politics and Culture in International History, p. 475.

54 J Rosenberg, 'The Secret Origins of the State: The Structural Basis of raison d'état', Review of International Studies, 18 (1992), pp. 131-59. 
'virtually monopolise East-West trade' sanctioned by diplomatic recognition. In Rosenberg's analysis politics and economics are combined rather than separated. The Italian city-states did have security concerns that forced them into territorial expansion; such factors are undeniable. But, as Rosenberg's analysis suggests, we cannot be entirely certain that security concerns were the main consideration. It seems more probable that 'their real location . . . was athwart the flows of exchange which serviced European feudalism and which carried their citizens into every major town and court in the continent. ${ }^{55}$ Thus, while the Italian city-states were no strangers to war, according to Rosenberg, military conflict was much more an instrument of private commercial interests than public political interests and was fought to secure and expand trade.

Rosenberg goes a long way towards establishing that any depiction of the origins of diplomacy needs to adopt an approach that identifies the combined nature of political and economic spheres. Woods' history of the Levant system of diplomacy provides detailed evidence of this. ${ }^{56}$ As with Italy in the same historical period, the interests of merchants drove the development of a diplomatic system in the Levant region, a diplomatic system linking some dozen states together and, moreover, extended to create connections between Levant states and Europe - including Italy. Confirmation from Woods then that the notion of an isolated Italian system of political diplomacy is indeed misleading and that diplomatic connections (driven by trading interests) developed between the European, Russian, Near East, Middle East and Far Eastern systems. ${ }^{57}$ Moreover, the details of the diplomatic system of the Levant show that a combined economic and political sphere was central to that system. ${ }^{58}$

Der Derian is also unwilling to accept the historical account given by classical scholars like Nicolson and, more specifically, Watson. Der Derian challenges the classical explanation of the evolution of diplomacy referring to such narratives as an 'abuse to history' on the grounds that they fail to explore the origins of diplomacy adequately and are therefore unable to demonstrate how the Italian diplomatic culture emerged and how it became the norm for other diplomatic systems. ${ }^{59}$ Buzan and Little also question some of the classical assumptions on which this account of the evolution of diplomacy is based. They point to the significance of a complex system of non-European international systems in world history in which 'prehistoric' systems of the ancient and medieval world not only differed from the European system, but were also linked together through processes such as trade processes that had 'some resemblance to diplomacy' ${ }^{60}$ Similarly, Liverani's study of the Armarna system reveals international relations of the Near East in the Late Bronze period characterised by ancient diplomatic practices in which relations are interpersonal, driven by kinship and commerce rather than the power politics

\footnotetext{
55 Rosenberg, 'The Secret Origins of the State', p. 144.

56 Woods, A History of the Levant Company.

57 See also V.J. Puryear, International Economics and Diplomacy in the Near East: A Study of British Commercial Policy in the Levant 1834-1853 (Archon Books, 1969).

58 Platt, Finance, Trade, and Politics; Platt, The Cinderella Service; Woods, A History of the Levant Company.

59 Der Derian, On Diplomacy, p. 3.

60 B. Buzan, and R. Little International Systems in World History: Remaking the Study of International Relations (Oxford: Oxford University Press, 2000), p. 159.
} 
associated with the later European system. ${ }^{61}$ These alternative histories suggest that diplomatic systems existed long before that of fifteenth century Europe and were constructed around various social processes.

\section{The political economy of diplomacy}

The prominent line of argument in the canon of diplomatic studies that sees a constitutive relationship between diplomacy and state sovereignty, as well as a constitutive relationship between diplomatic systems and an anarchic system of sovereign states, emerges from a particular reading of history that is informed more by rationalist inferences than by empiricism. In contrast to the arguments presented in this article, this orthodoxy fails to recognise, let alone explain, the commercial activity of diplomats as a core element of diplomatic practice. This is because the traditional approach to diplomacy privileges political transactions and neglects economic transactions. As a result a key analytical difficulty has always been present in diplomatic studies. Namely, the conceptual framework of much of the diplomatic studies literature means that it is ill-suited to the study of commercial diplomacy in general. Therefore, by corollary, it is also ill-equipped for a more particular study of the changes to diplomatic practice currently underway in several countries.

To shift to an approach that seeks to understand and explain these significant changes we need to think about diplomacy in a post-rationalist framework. Broadly speaking this requires an ontology based on open-ended historical narratives of diplomacy that does not tie diplomacy to the state and 'the anarchy problematique', but rather sees diplomacy as a means of connecting cultures, economies and states in order to build and manage social relations at domestic and systemic levels. Thus a political economy of diplomacy would identify changes to diplomatic practice as products of the interaction of economic and political, as well as cultural, ${ }^{62}$ discourse at domestic and systemic levels in particular historical periods.

Specifically if we are to understand and explain the functions and content of diplomatic practice we need to do what political economy does. We need to analyse social formation in diplomatic systems; that is, we need to disaggregate diplomatic systems so that we see diplomacy not as an instrument of an autonomous public actor (the state) but as an aggregate of public and private interests within the state similar to Jessop's strategic relational conception of the state as a social relation. ${ }^{63}$ In this way current diplomatic practice then becomes a product of current aggregates of interests, the precise mix of which varies in time producing changes to diplomatic practice. In this way we might explain current reforms to diplomatic practice in terms of moves by private interests to use public political authority (the state) to control the market.

61 M. Liverani, 'The Great Powers Club', in R. Cohen and R. Westbrook (eds.), Armana Diplomacy: The Beginnings of International Relations (Baltimore, MD: Johns Hopkins University Press, 2000). Note the exchange between Cohen and Berridge in this volume on whether the Armana constituted a diplomatic system.

62 We refer to the approach as a political economy of diplomacy because here we have concentrated on commercial linkages. However, this is not to miss the cultural bases of the economy. On which see, for example, B. Jessop and N.-L. Sum, 'Pre-disciplinary and Post-disciplinary Perspectives', New Political Economy, 6 (2001), pp. 89-101.

63 B. Jessop, State Theory: Putting the Capitalist State in its Place (Cambridge: Polity, 1990). 
Thus a political economy of diplomacy goes beyond the particular and narrow sense of the political, to a position where we recognise that economics matters in diplomacy. Not that we would wish to privilege economics in any essentialist manner, rather we see the necessity of integrating the political and the economic approach in order to help identify the linkages between public and private actors and interests - that is, the relationships between public and private within diplomatic systems. Then changes to diplomatic practice can be understood in terms of changes to public-private relationships within states that vary through time.

Adopting such an approach not only brings advantages to diplomatic studies, it also adds to our understanding of the international political economy in that it forces a recognition that agents - that is diplomats - are significant actors and part of a dense, yet unexplored, network of market actors in the world economy. After all, current commercial diplomacy - the promotion of inward and outward investment as well as exports - involves the search for competitive advantage in the world economy by diplomat-business alliances. An International Political Economy (IPE) agenda that includes analysis of current diplomatic practice with its emphasis on commercial diplomacy may well expose the connections between human agency and systemic transformation and stability - and thus add to debates about the relationship between structure and agency in IPE. By identifying diplomat-business alliances as significant actors in the world economy we are, to use Robert O'Brien's phrase, 'rediscovering human agency' ${ }^{\prime 64}$ and moving beyond the state-centred focus of some leading scholars in IPE. ${ }^{65}$ In recognising relationships between business and diplomats, an IPE agenda that includes the study of current diplomatic practice would also contribute to current IPE debates such as that over the 'privatisation' or 'marketisation' of the state and the issue of state capacity within the world economy. ${ }^{66}$ Thus we would claim that a political economy approach to diplomacy has a double advantage - it adds to the theoretical and empirical utility of diplomatic studies as well as IPE.

64 R. O’Brien, 'Labour and IPE: rediscovering human agency', in R. Palan (ed.) Global Political Economy: Contemporary Theories, RIPE Series in Global Political Economy (London: Routledge, 2000). On this point in relation to globalisation, see also C. Hay and D. Marsh (eds.), Demystifying Globalisation (Basingstoke: Palgrave, 2000).

65 R. Krasner, 'International Political Economy: Abiding Discord', Review of International Political Economy, 1 (1994), pp. 13-19. And for a critical response, S. Strange, 'Wake up, Krasner! The World Has Changed', Review of International Political Economy, 1 (1994), pp. 209-19.

66 There is a vast literature on state capacity in the global economy. An indicative bibliography includes S. Berger and R. Dore (eds.), National Diversity and Global Capitalism (Ithaca, NY: Cornell University Press, 1996); R Boyer and D. Drache, States Against Markets: The Limits of Globalisation (London: Routledge, 1996): P.G. Cerny, The Changing Architecture of Politics (London: Sage, 1990): P.G. Cerny, 'Paradoxes of the Competition State: The Dynamics of Political Globalisation', Government and Opposition, 32 (1997), pp. 251-74; I. Clark, Globalization and International Relations Theory (Oxford: Oxford University Press, 1999); C. Crouch and W. Streeck (eds.), Political Economy of Modern Capitalism: Mapping Convergence and Diversity (London: Sage, 1997); I. Douglas, 'Globalisation and the End of the State?', New Political Economy, 2 (1997), pp. 165-79; P. Evans, 'The Eclipse of the State? Reflections on Stateness in an Era of Globalization', World Politics, 50 (1997), pp. 62-87; G. Garrett, Partisan Politics in the Global Economy (Cambridge: Cambridge University Press, 1998); R.J. Holton, Globalisation and the Nation-State (London: Macmillan, 1998); C. May, 'States in the International Political Economy: Retreat or Transition?', Review of International Political Economy, 5 (1998), pp. 157-63; K. Ohmae, The Borderless World (London: Collins, 1990); K. Ohmae, The End of the Nation State (New York: Free Press, 1995); L. Panitch, 'Rethinking the Role of the State', in J.H. Mittelman (ed.), Globalization: Critical Reflections (London: Lynne Reinner, 1997); S. Strange, The Retreat of the State: The Diffusion of Power in the World Economy (Cambridge: Cambridge University Press, 1996); L. Weiss, The Myth of the Powerless State (Cambridge: Polity, 1998). 


\section{Conclusion}

Because of the predominantly rationalist approach to diplomacy - an approach that is based largely on a statist reading of international relations - much of the diplomatic studies literature is unable to perceive, let alone analyse, the commercial elements of diplomacy. Thus to date, commercial diplomacy has suffered a presentbut-invisible status within diplomatic studies. This blindness produces a partial disclosure of what constitutes diplomatic practice. By using diplomatic memoirs, government records as well as alternative studies of the origins and development of diplomacy, we can overcome this blindness and provide ample evidence of the significance and continued presence of the commercial elements in diplomacy. Indeed, contemporary changes to the institutions and practice of diplomacy have created a diplomatic practice in which the balance between the commercial elements and political elements of commercial work has swung very much in favour of the former.

At present there is a clear disjuncture between the theory of diplomacy and diplomatic practice. Most diplomatic theorists would have us believe that diplomacy is the stuff of high politics, yet we know that this position obscures the practice of a diplomacy that is far more complex and multifaceted. Not only do we know this intuitively, diplomats and official government records tell us that this is so. More significantly, we also know that commercial elements of diplomacy have always been embedded in diplomatic practice; diplomats have always undertaken commercial activities. As long as theories of diplomacy continue to divorce market relations from political relations when understanding international relations, there is always the danger of masking the commercial elements of diplomacy.

In this article we have shown the necessity of adopting a political economy approach that integrates market relations with political relations and thus conceptualises diplomacy as a continuous political-economic dialogue. We have also cleared the ground for such an approach. We have begun to develop the necessary analytical tools to better understand and explain the multi-dimensional nature of diplomacy, including its commercial element. We do not claim to have produced a new way of theorising diplomacy. Rather we have provided a different conceptualisation of diplomacy, one that integrates diplomatic studies with IPE, so that we can develop an agenda in diplomatic studies that can better identify the commercial diplomacy in general and explain the changes now underway in diplomatic institutions and practice in particular. As we have shown, these changes are best understood in terms of an unbroken diplomatic tradition of the marriage between public and private actors and interests that is evident in the origins and evolution of diplomacy and diplomatic systems. Far from being a weakening of diplomacy, the contemporary changes are easily accommodated inside the diplomatic tradition. Focusing upon the key characteristics of the contemporary changes - the development of new institutions and the formal inclusion of business representatives and thus business interests - is important. Not because it helps us reach artificial conclusions about the demise or resilience of traditional diplomacy, but rather because it provides a means to identify and understand the change in public-private relationships within state structures - an issue that is already of current academic concern within IPE but much overdue in diplomatic studies. 